Jurnal IImiah KONTEKSTUAL

Volume 3, No. 01, Agustus 2021, p. 15-25

\title{
PERSEPSI DAN KENDALA GURU SD MENGENAI SISTEM BDR (BELAJAR DARI RUMAH)
}

\author{
ELEMENTARY SCHOOL TEACHERS PERCEPTIONS AND \\ DIFFICULTIES ABOUT BDR SYSTEM
}

\author{
Monika Handayani*1, Yoan Dendi Pradana ${ }^{2}$, \\ Pendidikan Guru Sekolah Dasar, Fakultas Keguruan dan Ilmu Pendidikan, Universitas Terbuka, Banten, \\ Indonesia ${ }^{1}$, SD Negeri Pondok Cabe Ilir 02, Tangerang Selatan, Indonesia \\ e-mail:*1monika@ecampus.ut.ac.id, ${ }^{2}$ yoan.dendi@gmail.com
}

\begin{abstract}
ABSTRAK
Kebijakan belajar di rumah (BDR) yang diterapkan oleh pemerintah karena pandemi covid-19 menjadi hal baru yang baru di dunia pendidikan. Hal tersebut pasti menjadi masalah yang cukup berarti bagi guru dan siswa. Guru harus berpikir kreatif untuk mampu menghasilkan pembelajaran yang dapat dilakukan oleh siswa. Penelitian ini difokuskan pada pemahaman guru mengenai BDR dan cara guru melaksanakan kegiatan BDR serta kendala yang dialami guru pada kegiatan BDR ini. Jenis penelitian termasuk jenis penelitian kualitatif deskriptif. Subjek penelitian ini adalah guru di kabupaten Purbalingga sedangkan waktu penelitian ini dilakukan selama 6 bulan. Teknik dan instrumen pengambilan data pada penelitian disesuaikan dengan situasi yang terjadi saat ini karena covid-19 sehingga dilakukan wawancara dengan pedoman wawancara via online. Teknik analisis data akan dilakukan menggunakan teknik analisis Miles dan huberman. Hasil penelitian menjelaskan bahwa penerapan kegiatan BDR oleh guru SD di Purbalingga dilakukan dengan blended learning karena disesuaikan dengan kondisi siswa yang tidak memungkinkan jika hanya menerapkan pembelajaran daring. Selanjutnya, dari hasil penelitian juga menjelaskan kesulitan yang dialami guru dan siswa yaitu keterbatasan gadget dan jaringan serta kesulitan melakukan penilaian dalam kegiatan BDR.
\end{abstract}

Kata kunci: Belajar Dari Rumah, Pandemi, Covid-19, Pembelajaran Daring, Blended Learning

\begin{abstract}
Belajar Dari Rumah (BDR) policy that implemented by the government due to the COVID-19 pandemic is a new thing in the world of education. This must be a significant problem for teachers and students. Teachers must think creatively to be able to produce learning that can be done by students. This research is focused on teachers' understanding of BDR and how teachers carry out BDR activities as difficulty experienced by teachers in this BDR activity. This type of research includes descriptive qualitative research. The subjects of this study were teachers in Purbalingga district, while the time of this research was 6 months. The data collection techniques and instruments in the study were adapted to the current situation due to the covid-19, so interviews were conducted using online interview guidelines. Data analysis techniques will be carried out using Miles and Huberman analysis techniques. The results of the study explained that the implementation of BDR activities by elementary school teachers in Purbalingga was carried out using blended learning because it was adapted to student conditions which would not allow only online learning. Furthermore, the results of the study also explain the difficulties experienced by teachers and students, namely the limitations of gadgets and networks as well as difficulties in conducting assessments in BDR activities.
\end{abstract}

Keywords: Learning From Home, Pandemic, Covid-19, Online Learning, Blended Learning 


\section{PENDAHULUAN}

Pandemi Covid-19 yang melanda seluruh dunia menjadi permasalahan serius dalam berbagai bidang terutama bidang pendidikan. Kebijakan Presiden dan Menteri Pendidikan yang menerapkan belajar dari rumah (BDR) menjadi fokus perhatian dari berbagai pihak terutama guru. Pada kenyataannya, penerapan BDR di sekolah formal menjadi tantangan sulit bagi pendidik, siswa dan orang tua khususnya di negera berkembang dengan ketersediaan dan aksesbilitas teknologi yang tidak merata [1]. Hal tersebut karena, kegiatan BDR yang dilakukan siswa dengan dibantu oleh orang tua merupakan kegiatan yang jarang terjadi di sekolah formal kecuali pada pendidikan non formal seperti home schooling.

Sesuai dengan Surat Edaran Menteri nomor 4 tahun 2020 tentang Pelaksanaan Kebijakan Pendidikan dalam Masa Darurat Penyebaran Coronavirus Disease (Covid-2019) menjelaskan bahwa proses belajar dari rumah dilaksanakan melalui pembelajaran daring/jarak jauh. Pembelajaran daring merupakan salah satu model pembelajaran yang dilakukan dengan menggunakan perangkat teknologi di tengah pandemi saat ini [2]. Penerapan pembelajaran daring dalam Pembelajaran Jarak Jauh (PJJ) juga menimbulkan masalah baru karena pembelajaran daring sangat tergantung dengan ketersediaan jaringan dan teknologi yang ada. Sementara fakta di lapangan dari hasil penelitian yang dilakukan oleh Badan Keahlian DPR RI yang menjelaskan banyak pendidik yang mengeluhkan terbatasnya ketersediaan sarana teknologi bahkan jaringan yang tidak ada sama sekali [3]. Berdasarkan hasil penelitian tersebut, perlunya solusi yang tepat dan kreativitas bagi guru agar mampu merumuskan strategi pembelajaran yang tepat sesuai dengan kondisi siswa dan lingkungan sekitarnya.

Berdasarkan survey yang dilakukan KPAI ditemukan jika selama aktivitas BDR banyak orang tua siswa yang mengeluhkan aktivitas belajar anaknya menjadi lebih berat karena dibebankan tugas-tugas oleh guru (Sumber: https://www.kpai.go.id/publikasi/ada-246-aduan-dikpai-soal-belajar-daring-siswa-keluhkan-tugas-menumpuk-kuota). Selain itu, proses pembelajaran daring secara virtual mendorong guru lebih memadatkan materi ajar yang didukung dengan metode yang tepat karena minimnya waktu dan resiko biaya aplikasi yang digunakan [4]. Akibatnya guru memberikan tugas secara berlebihan kepada siswa dengan harapan seluruh siswa mampu mencapai ketuntasan materi pembelajaran. Sedangkan, menurut Surat Edaran Mendikbud No. 4 Tahun 2020 kegiatan BDR difokuskan pada pengalaman belajar yang nyata dan kecakapan hidup tanpa dituntut untuk menuntaskan keseluruhan capaian kurikulum atau kenaikan kelas [5]. Sebenarnya jika guru mencermati peraturan tersebut maka guru tidak perlu mendorong siswa untuk mencapai ketuntasan materi belajar tetapi membekali siswa dengan kecakapan belajar yang cukup di masa pandemi saat ini.

Kesuksesan BDR sangat bergantung pada berbagai faktor baik dari pihak-pihak yang terlibat (guru, siswa dan wali murid) dan juga pada kondisi lainnya (sinyal, gadget/alat dan bahan belajar lainnya). Faktor yang paling penting adalah kerja sama yang baik antara guru, wali murid, dan siswa sendiri. Sementara pada kenyataannya, efektivitas model pembelajaran daring sangat ditentukan oleh sistem jaringan telekomunikasi sebagai perangkat penunjang yang paling utama. [6]. Fakta dilapangan kegiatan BDR dengan sistem pembelajaran daring dan PJJ tidak dapat sepenuhnya diterapkan karena keterbatasan jaringan dan teknologi terutama pada daerah-daerah yang bukan perkotaan dengan segala kekurangan di berbagai bidang. Sistem pembelajaran daring juga menuntut kemampuan penguasaan teknologi guru dan orang tua sehingga penerapannya tidak semudah yang dijelaskan karena bergantung pada kompentensi guru dan kemampuan orang tua.

Pembelajaran daring pada masa pandemi dilakukan dengan menggunakan perangkat gadget bertujuan untuk menghubungkan siswa dengan guru melalui pemanfaatan teknologi tersebut proses belajar mengajar bisa tetap dilaksanakan dengan baik.[7]. Selain penguasaan teknologi informasi, guru juga dituntut memiliki perangkat gadget (HP, Laptop, dan lainnya) dan aplikasi yang digunakan dalam kegiatan pembelajaran. Namun, faktor lain yang perlu diperhatikan guru adalah kondisi siswa dan orang tua terhadap aksesnya terhadap teknologi. Seperti yang dijelaskan dalam Panduan Pembelajaran Jarak Jauh Selama Covid-19 Tahun 2020 menjelaskan bahwa yang perlu diperhatikan guru dalam merencanakan BDR yaitu mengetahui akses teknologi siswa 
seperti kepemilikan, jenisnya, lamanya, biayanya, dan bagaimana cara siswa mengaksesnya materi dan bagaimana orang tua dan wali murid yang membantu siswa belajar sehingga guru dapat menentukan siapa yang paling membutuhkan bantuan [8]

Berdasarkan uraian permasalahan dan kajian pustaka tersebut, penelitian ini difokuskan pada pemahaman guru terhadap pengaplikasian kegiatan BDR yang telah dilakukan khususnya di kabupaten Purbalingga. Selain itu, kendala guru dalam proses BDR dan tindakan yang telah dilakukan oleh guru dalam mengatasi kendala tersebut. Dengan demikian, tujuan penelitian yaitu 1) mengetahui persepsi atau pemahaman guru sekolah dasar di Purbalingga terhadap sistem BDR, 2) mengetahui pola pelaksanaan sistem BDR yang dilakukan oleh guru sekolah dasar di Purbalingga, dan 3) mengetahui hambatan atau kendala yang dihadapi guru sekolah dasar di Purbalingga dalam melaksanakan sistem BDR.

\section{METODE PENELITIAN}

Penelitian yang dilakukan termasuk jenis penelitian deskriptif kualitatif. Subjek penelitian ini adalah 12 orang guru sekolah dasar di kabupaten Purbalingga Provinsi Jawa Tengah. Subyek penelitian dipilih berdasarkan teknik sample random sampling. Waktu penelitian dilakukan selama 6 bulan terhitung dari bulan Agustus 2020 sampai dengan Januari 2021.Teknik pengumpulan data yang digunakan adalah angket secara daring dan wawancara semi terstruktur. Angket digunakan untuk mengumpulkan informasi umum guru sedangkan wawancara mendalam dilakukan untuk mengetahui proses penerapan BDR yang telah dilakukan oleh guru. Teknik analisis data menggunakan metode Miles and Huberman yaitu dengan cara reduksi data, penyajian data dan penarikan kesimpulan. Berikut adalah pedoman wawancara semi terstruktu terstruktur pada Tabel 1

Tabel 1 Pedoman Poin-Poin Wawancara

\begin{tabular}{ll}
\hline No & Daftar Pertanyaan \\
\hline 1 & Pemahaman Mengenai kegiatan BDR \\
\hline 2 & Pelaksanaan kegiatan BDR \\
\hline 3 & Penggunaan Aplikasi dalam kegiatan BDR \\
\hline 4 & Kerjasama dengan orang tua/wali murid dalam kegiatan BDR \\
\hline 5 & Kendala yang dihadapi dalam kegiatan BDR \\
\hline 6 & Ketersediaan Sarana Prasarana siswa dalam kegiatan BDR \\
\hline 7 & Kelebihan dan Kelemahan kegiatan BDR \\
\hline 8 & Sarana dan Prasarana yang digunakan dalam kegiatan BDR \\
\hline 10 & Dukungan Sekolah atau Instansi dalam kegiatan BDR \\
\hline
\end{tabular}

\section{HASIL DAN PEMBAHASAN}

\section{Hasil Penelitian}

Hasil penelitian dianalisis menggunakan analisis kualitatif dari hasil wawancara terhadap 11 guru SD sebagai responden. Berikut disajikan pada Tabel 2 deskripsi informasi masing-masing responden sebagai gambaran.

Tabel 2 Deskripsi Responden Penelitian

\begin{tabular}{llllll}
\hline No & Nama Guru & $\begin{array}{l}\text { Kelas } \\
\text { Ampuan }\end{array}$ & $\begin{array}{l}\text { Lama } \\
\text { Mengajar }\end{array}$ & Instansi & $\begin{array}{l}\text { Jumlah } \\
\text { siswa }\end{array}$ \\
\hline 1 & RB & 4 & 6 tahun & SD N 1 Limbasari & 19 siswa \\
\hline 2 & SR & 6 & 6 tahun & SD N 1 Purbalingga Wetan & 34 siswa \\
\hline 3 & RA & 6 & 6 tahun & SD N 1 Grecol & 30 siswa \\
\hline 4 & GE & 5 & 6 tahun & SD N 1 Selakambang & 24 siswa \\
\hline 5 & LH & 5 & 6 tahun & SD N 1 Palumbungan Wetan & 25 siswa \\
\hline 6 & RS & 3 & 6 tahun & SD N 1 Purbalingga Kidul & 27 siswa \\
\hline 7 & SDRD & 4 & 2 tahun & SD N 1 Purbalingga Kulon & 24 siswa \\
\hline 8 & P & 4 & 8 tahun & SD N 3 Selakambang & 30 siswa \\
\hline
\end{tabular}


Jurnal Ilmiah KONTEKSTUAL, Volume.3, No.01, Agustus 2021, pp. 15-25

\begin{tabular}{llllll}
\hline 9 & RSY & 3 & 6 tahun & SD N 1 Tetel & 25 siswa \\
\hline 10 & SJ & 6 & 6 tahun & SD N 2 Pagerandong & 22 siswa \\
\hline 11 & AMA & 6 & 2 tahun & SD N 1 Bedagas & 22 siswa \\
\hline 12 & HP & 5 & 31 tahun & SD N 2 Penolih & 24 siswa \\
\hline
\end{tabular}

Berdasarkan data yang ditunjukan pada Tabel 2 diketahui bahwa instansi tempat responden yang berbeda-beda dan tersebar di seluruh wilayah kabupaten Purbalingga. Artinya jawaban yang diberikan oleh masing-masing guru baik di wilayah perkotaan maupun pedesaan jika tidak berarti pasti akan berbeda namun dari hasil wawancara yang dilakukan oleh peneliti menemukan kesamaan yang sama dari setiap guru terutama mengenai kesulitan yang dihadapi pada saat kegiatan BDR.Selain itu, responden juga memiliki pengalaman mengajar yang bervariasi tetapi rata-rata berada memiliki pengalaman mengajar 6 tahun sehingga praktek di lapangan mengenai kegiatan BDR dapat berbeda namun ternyata hampir sama. Untuk lebih jelasnya, berikut hasil wawacara yang diperoleh pada saat penelitian dilakukan.

\section{Pemahaman guru mengenai kegiatan BDR}

Hasil wawancara terhadap 12 guru sekolah dasar di Purbalingga memiliki jawaban yang serupa mengenai pemahaman kegitan BDR. Menurut guru, kegiatan BDR merupakan sistem belajar dari rumah yang dilakukan siswa bekerja sama dengan orang tua/wali murid karena dampak adanya pandemic covid -19 sehingga Pendidikan tetap terlaksana. Berikut sampel wawancara yang dilakukan dengan guru.

BDR belajar dari rumah, kalo menurut saya bukan hanya belajar secara online atau daring saja, namun bisa berupa belajar yang lebih luas, bisa daring bisa luring disesuaikan dengan kondisi dan daerah masing-masing. namun siswa tidak datang ke sekolah (RSY)

Kegiatan BDR itu menurut saya berisi instruksi dan penugasan. Siswa bisa belajar sendiri melalui internet maupun buku-buku yang ada di rumah atau dapat melalui youtube, siaran televisi, ruang guru dan aplikasi-aplikasi belajar lainnya (RB)

Berdasarkan hasil wawancara tersebut, dapat diketahui bahwa kegiatan BDR adalah kegiatan belajar dari rumah pada masa pandemi covid- 19 yang mempermudah guru menyampaikan pembelajaran kepada siswa disesuaikan dengan kondisi siswa. Dengan demikian, kegiatan BDR dapat dilakukan secara daring dan tatap muka tetapi disesuaikan dengan peraturan pemerintah yang berlaku.

\section{Pelaksanaan kegiatan BDR}

Guru melaksanakan kegiatan BDR secara blended learning yang artinya tidak hanya berbasis pembelajaran daring tetapi juga dengan melakukan pembelajaran tatap muka melalui pokjar (kelompok belajar) yang disesuaikan dengan protokol kesehatan. Selain itu, untuk pembelajaran daring sendiri guru membentuk grup WhatsApp Group (WAG) sebagai komunikasi dan pemberian tugas.

Karena kesadaran siswa belajar menggunakan internet masih minim jadi saya lakukan solusi tatap muka di rumah siswa. Ini pun belum maksimal, karena seminggu hanya 3 kali pertemuan dan durasi paling lama 2 jam. 1 kelompok terdiri dari 6 siswa. Tatap muka dilakukan untuk membahas materi yang sekiranya sulit jika hanya dilakukan dengan daring seperti matematika apalagi saya mengampu kelas 6 (RA)

Untuk tata cara BDR yang saya lakukan, pertama saya membentuk grup Whatsapp paguyuban dan setiap hari melalui $\mathrm{WaG}$ kita mengkomunikasikan cara-cara BDR contohna hari ini dengan menggunakan video pembelajaran atau foto-foto materi dan tugas (RSY) 
Berdasarkan hasil wawancara tersebut diketahui bahwa pelaksanaan BDR yang dilakukan oleh guru melalui $\mathrm{WaG}$ (pembelajaran daring) dan pembelajaran tatap muka melalui pokjar. Kelompok belajar yang dibentuk berkisar 5-6 siswa. Kelompok belajar ini dikhususkan untuk mengajarkan beberapa materi yang dianggap sulit jika hanya sebatas mengajarkan dalam pembelajaran daring.

\section{Kerjasama yang dilakukan dengan orang tua atau wali}

Kegiatan BDR erat kaitannya dengan kerjasama antara orang tua atau wali murid dengan guru dalam membimbing siswa belajar di rumah. Oleh sebab itu peran orang tua sangat besar dalam keberhasilan BDR. Berikut penggalan hasil wawancara mengenai kerjasama yang dilakukan oleh guru dengan orang tua atau wali murid

Kerja sama dengan orang tua sudah cukup baik, tetapi dikembalikan lagi ke keluarga masing-masing siswa. Ada yang orang tuanya sibuk bekerja, ada juga orang tuanya kurang memahami materi pembelajaran dan ada orang tuanya yang sangat aktif meminta tugas. Jadi disesuaikan porsinya masing-masing yang terpenting guru sudah mengingatkan dan menjalin komunikasi dengan orang tua. (AMA)

Kami bekerja sama membuat jadwal untuk belajar di rumah. Setiap saya kirim tugas untuk siswa, saya batasi waktu untuk pengerjaan dan pengiriman tugasnya. Namun, jika ada yg terkendala HP nya dibawa oleh orang tua bekerja, saya beri kelonggaran waktu sampai malam hari. (GE)

Berdasarkan hasil penelitian diketahui bahwa pendampingan orang tua dalam kegiatan BDR sangat berperan khususnya dalam memantau kegiatan belajar siswa dirumah. Meskipun pada awalnya guru dan orang tua kesulitan dengan penerapan sistem BDR. Hal ini disebabkan ketidaksiapan orang tua yang harus menjadi pengganti guru untuk membimbing [9]. Namun, pada akhirnya orang tua dan guru dipaksa untuk mampu beradaptasi dengan sistem BDR sehingga kerjasama tetap harus dibina untuk mengurangi kesulitan dalam penerapan BDR.

\section{Ketersediaan Sarana Prasarana yang dimiliki oleh Siswa}

Perangkat seperti HP, Laptop, Komputer dan lainnya memang erat kaitannya dalam kegiatan BDR. Namun, dari hasil wawancara dengan 12 guru diketahui jika 9 guru mengaku memiliki siswa yang tidak memiliki HP sebagai perangkat utama dalam kegiatan BDR. Berikut penggalan hasil wawancara yang dilakukan dengan guru.

Kalau untuk HP sebagian kecil siswa ya sekitar 30\% siswa belum memiliki HP. Biasanya siswa yang belum memiliki HP menggunakan HP saudara atau ikut teman terdekat rumahnya. Cuma ya sinyal dan jaringan juga sulit diakses, biasanya siswa harus pindah tempat atau lokasi untuk memperoleh jaringan. (SJ)

Untuk keseluruhan siswa sudah memiliki HP maksudnya HP bersama dengan orang tua karena mungkin ini siswa diperkotaan. Akan tetapi, jika orang tua bekerja HP tersebut juga dibawa orang tuanya sehingga biasanya pengumpulan tugasnya dan penyampaian materi menjadi terhambat. (SDRD)

Berdasarkan hasil penelitian menjelaskan bahwa pelaksanaan kegiatan BDR dengan sepenuhnya daring sulit dilakukan terutama bagi siswa di pedesaan karena masalah HP dan sinyal serta jaringan yang minim. Hal tersebut yang mendorong guru menerapkan blended learning pada kegiatan BDR melalui pokjar yang dibatasi setiap minggunya. Meskipun dinilai belum efektif tapi kegiatan belajar melalui pokjar mampu menjadi solusi bagi guru yang memiliki siswa dengan berbagai kekurangan pada sarana dan prasarana dalam kegiatan BDR. 


\section{Kendala yang dihadapi dalam kegiatan BDR}

Seperti yang telah diuraikan sebelumnya, kendala yang paling umum dihadapi dalam penerapan kegiatan BDR adalah sarana prasana seperti perangkat gadget dan jaringan. Hal tersebut bisa dipengaruhi karena pemilihan lokasi penelitian yang berada di Kabupaten Purbalingga. Namun, sebenarnya jika dicermati lokasi penelitian masih berada di Pulau Jawa yang diketahui memiliki akses jaringan lebih baik dibanding pulau-pulau lainnya di Indonesia. Berikut potongan wawancara dengan guru mengenai kendala yang dihadapi.

Beberapa kendala yang saya hadapi:

1. Tantangan dari segi teknologi, tidak semua siswa/orangtua murid mampu memanfaatkan HP untuk kegiatan belajar, aplikasi atau web yg digunakan digunakan untuk pembelajaran tidak semua dapat dioperasikan oleh siswa/orangtua murid, meskipun tentunya ada peran guru juga disini memberikan tutorial cara menggunakan aplikasi yang digunakan dalam pembelajaran

2. Tantangan lokasi, di daerah pedesaan terutama kebanyakan siswa sulit mendapatkan sinyal

3. Kuota belajar, sebagian besar siswa mengandalkan kuota belajar yang diberikan dari sekolah ataupun Kemendikbud sehingga ketika kuota habis tidak semua siswa mampu langsung membeli.

4. Materi pembelajaran, materi yang menurut siswa sulit dipahami maka siswa pun mengalami kesulitan dalam menangkap materi tersebut karena tidak bertatap muka secara langsung dengan guru,terutama materi matematika

5. Pemanfaatan HP untuk belajar, HP digunakan untuk belajar selesai maka siswa cenderung akan bermain game atau bahkan siswa lebih senang bermain game daripada memanfaatkan HP untuk belajar sehingga tugas2 siswa terganggu. (SJ)

Kendalanya seperti yang sudah dijelaskan tadi, tidak semua siswa memiliki HP lalu jaringan dan kuota. Karena daerah siswa lokasinya di pedesaan banyak siswa yang kesulitan mengakses informasi melalui HP sehingga tidak memungkinkan saya menggunakan video berdurasi lama untuk menjelaskan materi yang sulit. Lalu pemanfaatan HP banyak anak yang menggunakan HP tidak hanya untuk belajar tetapi bermain game dan itu juga dikeluhkan oleh orang tua siswa. Lalu kesulitan lain, kita tidak bisa mengetahui apakah tugas yang diberikan kepada siswa benar-benar dikerjakan oleh siswa (LN)

Berdasarkan hasil wawancara tersebut, dapat diketahui kesulitan dari kegiatan BDR selain dari sarana prasarana yang kurang adalah pemanfaatan media komunikasi (HP) yang semestinya untuk kegiatan belajar tetapi belum sepenuhnya efektif digunakan untuk kegiatan belajar. Selain itu, sulitnya mengontrol disiplin siswa dalam mengerjakan tugas dan mengumpulkan tugas. Hal ini karena, pemberian tugas yang diberikan oleh guru biasanya dianggap beban oleh siswa dan orang tua. Meskipun, sebenarnya pemberian tugas tersebut adalah sebagai proses yang digunakan siswa untuk lebih mudah dalam memahami materi [6]. Oleh sebab itu pentingnya guru dan orang tua menjelaskan pentingnya bagi siswa mengerjakan tugas yang disesuaikan dengan kemampuan dan karakteristik siswa.

\section{Penggunaan aplikasi dalam kegiatan BDR}

Sistem pembelajaran daring pada masa pandemi ini memunculkan banyak platform belajar yang dapat digunakan oleh guru dalam menfasilitasi belajar siswa. Namun, berbagai platform aplikasi belajar daring justru menyulitkan guru dan menuntut orang tua memahami penggunaan berbagai platform tersebut [2]. Hal tersebut, juga terjadi pada kegiatan BDR di Purbalingga, berikut cuplikan hasil wawancara dari beberapa guru.

Aplikasi selain WaG yang biasa saya gunakan untuk Ulangan Harian setiap Subtema adalah google form, tetap dominan ke WaG, untuk jenjang Sekolah Dasar menggunakan 
Jurnal Ilmiah KONTEKSTUAL, Volume.3, No.01, Agustus 2021, pp. 15-25

aplikasi lain seperti Google clasroom, zoom meet, ofice365 saya rasa tidak bisa optimal, bahkan di sekolah-sekolah pedesaan masih sulit diterapkan $(\mathrm{P})$

Iya bu, itu aplikasi utama yang dipakai. WhatsApp sekarang untuk berkomunikasi dengan orang tua, sedangkan Google classroom pembelajaran dengan siswa. Tapi saya juga menggunakan aplikasi tambahan seperti Google form dan Quizizz untuk memberikan tugas, tapi tidak semua tugas pakai itu saia. (SR)

Berdasarkan hasil penelitian, diketahui pada umumnya guru dan siswa memakai WaG karena $\mathrm{WaG}$ lebih familiar digunakan oleh orang tua. Sedangkan untuk penggunaan aplikasi lain disesuaikan dengan kondisi pada siswa. Pada siswa di perkotaan aplikasi lain seperti google classroom, youtube, zoom meeting dapat dengan mudah diakses namun berbanding terbalik dengan siswa di pedesaan umumnya hanya menggunakan $\mathrm{WaG}$ dan satu atau dua aplikasi lainnya karena terkendala gadget dan sinyal jaringan.

\section{Kelebihan dari kegiatan BDR}

Dibalik kesulitan yang dihadapi dalam kegiatan BDR, guru juga merasakan adanya kelebihan dalam kegiatan ini. Salah satunya adalah mengurangi interaksi tatap muka yang mampu menekan angka positif covid-19. Berikut hasil penggalan wawancara yang diperoleh dengan guru.

Melatih kemandirian belajar siswa karena dengan adanya BDR ini, mau tidak mau siswa harus mampu membuat jadwal belajar Bersama orang tua dan belajar secara mandiri. Selain itu, menumbuhkan jalinan komunikasi yang lebih erat dengan orang tua atau murid. (SDRD)

Keunggulan : Disamping mampu menekan penularan Covid, mampu menumbuhkan rasa kesadaran orang tua bahwa pendidikan anak tidak hanya sepenuhnya dibebankan pada sekolah, dan terjalinnya komunikasi dengan baik antara guru, siswa dan orang tua. Guru juga mau tidak mau harus melek teknologi dan menyesuaikan dengan pembelajaran khususnya dalam jaringan. Belajar mengelola pembelajaran daring dari yang paling sederhana yaitu WaG. (P)

Berdasarkan hasil penelitian, dapat diketahui bahwa kelebihan lain dari kegiatan BDR adalah menumbuhkan kesadaran orang tua untuk lebih peduli dan ikut mengontrol kegiatan belajar anaknya selama di rumah. Selain itu, kegiatan BDR menuntut guru dan orang tua juga untuk mengikuti perkembangan zaman terutama dalam penggunaan teknologi yang mampu mendorong siswa dalam kegiatan belajarnya.

\section{Kelemahan dari kegiatan BDR}

Kelemahan dari kegiatan BDR yang dirasakan oleh guru hampir sama dengan kendala yang dilalui dalam pelaksanaan kegiatan BDR. Guru mengeluhkan pembelajaran daring yang sulit dilakukan karena kekurangan pada sarana prasarana dan jaringan sedangkan untuk pertemuan tatap muka dilakukan dibatasi berapa kali dalam setiap minggunya. Hal tersebut, berdampak pada pemberian materi yang terserap kurang maksimal, Berikut potongan hasil wawancara yang diperoleh dengan guru.

Menurut saya kegiatan BDR ini banyak kekurangannya. Mulai dari keterbatasan komunikasi menggunakan sistem online, karena siswa disini belum 100\% mempunyai alat komunikasi berupa HP. Belum lagi ketika kita ingin menjelaskan materi-materi yang sulit kepada siswa kan tingkat pemahaman siswa berbeda-beda. Ada yang bisa memahami materi dengan cara membaca saja, tapi kebanyakan mereka membutuhkan penjelasan yang berulang-ulang dari guru. Selain itu anak-anak masih kurang adanya pengawasan waktu belajarnya. Mereka cenderung mengabaikan waktu belajar alias 
Jurnal Ilmiah KONTEKSTUAL, Volume.3, No.01, Agustus 2021, pp. 15-25

menunda-nunda belajarnya sehingga beberapa diantara mereka ada yg tidak mengumpulkan tugas kepada kami tepat waktu. (GE)

Kelemahannya banyak $\mathrm{Bu}$, jaringan di tempat siswa ada yang jaringan apapun tidak masuk sehingga jika memberikan tugas sulit. Lalu karakteristik orang tua yang kebanyakan petani dan kurang memahami materi pembelajaran siswa sehingga siswa butuh tatap muka terutama untuk materi seperti matematika yang butuh pemahaman. Selain itu, tidak setiap siswa juga memiliki HP sehingga menjadi kendala juga dalam memberikan tugas (HP)

Berdasarkan hasil penelitian ditemukan bahwa kelemahan paling besar yang dihadapi guru adalah ketersediaan jaringan dan gadget selama kegiatan BDR. Selain itu, perlunya kontrol yang dilakukan oleh guru bekerjasama dengan orang tua siswa selama BDR. Kontrol atau pengawasan tersebut seperti apakah siswa mengerjakan tugas yang diberikan, apakah siswa belajar, bagaimana siswa mengerjakan tugas dan lainnya. Kegiatan tersebut yang perlu dikolaborasikan dengan baik antara guru dan orang tua sehingga BDR dapat berjalan dengan efektif.

\section{Sarana prasarana yang digunakan dalam kegiatan BDR}

Penggunaan sarana prasarana dalam kegiatan BDR tentunya memiliki perbedaan dengan kegiatan belajar secara tatap muka. Guru menjelaskan penggunaan gadget terutama HP menjadi sarana utama yang menghubungkan kegiatan belajar antara guru, siswa dan orang tua. Selain itu, prasarana lain seperti aplikasi dan jaringan yang disesuaikan dengan kondisi dan karakteristik siswa. Berikut potongan wawancara yang diperoleh dengan guru.

Sarana prasarana tidak jauh berbeda hanya HP dan laptop sumber utama selain itu biasanyakertas Manila/kertas HVS dan spidol untuk mendukung kegiatan belajar siswa (SJ)

Untuk sarana prasarana pasti HP untuk komunikasi. Laptop untuk merancang tugas dan bahan ajar lainnya. Lalu bahan ajar lainnya menggunakan Buku siswa, LKS, sama video-video pembelajaran yang mendukung materi. (SR)

Hasil penelitian menemukan bahwa guru menggunakan gadget seperti HP dan laptop untuk merancang, melaksanakan dan mengevaluasi kegiatan BDR. Selain itu, siswa juga dilengkapi dengan buku ajar teks, LKS dan media lain yang digunakan untuk melakukan kegiatan proyek selama kegiatan BDR. Kegiatan berbasis proyek banyak dilakukan oleh guru untuk mendukung keterampilan psikomotornya selama kegiatan BDR dan lebih menantang siswa sehingga siswa tidak mudah bosan.

\section{Dukungan sekolah dan instansi pada kegiatan BDR}

Kegiatan BDR merupakan kegiatan yang diterapkan pada masa pandemi sesuai peraturan pemerintah. Oleh sebab itu, kegiatan BDR yang dilakukan guru seharusnya didukung dengan fasilitas dari sekolah maupun instansi terkait. Berikut cuplikan wawancara dengan guru.

Untuk bantuan dari instansi dinas ada bantuan kuota untuk guru dan siswa selama kegiatan BDR. Dari sekolah sendiri itu saya dikasih Tablet. Lalu dari sekolah juga meminjamkan buku teks untuk dipelajari siswa dan juga LKS untuk mendampingi siswa selama BDR. (HP)

Bantuan dari sekolah laptop. Instansi itu kuota untuk guru dan murid. (RSY)

Berdasarkan hasil dari wawancara tersebut, diketahui bahwa dukungan sekolah dan instansi dalam kegiatan BDR yang paling utama kuota sesuai dengan wacana dari pemerintah pemberian 
Jurnal Ilmiah KONTEKSTUAL, Volume.3, No.01, Agustus 2021, pp. 15-25

kuota data internet tahun 2020 selama BDR. Selain itu, dukungan dari sekolah seperti penyediaan LKS dan buku teks untuk mendampingi siswa belajar di rumah dan tablet atau sepeda kepada guru. Dukungan tersebut dirasakan guru sudah lebih baik meskipun masih banyak kendalakendala yang dihadapi dalam pelaksanaan BDR.

\section{Proses evaluasi yang dilakukan pada kegiatan BDR}

Dalam kegiatan BDR juga dilakukan proses evaluasi seperti PTS (Penilaian Tengah Semester) dan PAS (Penilaian Akhir Semester). Proses kegiatan ini juga dilakukan sesuai dengan peraturan penyelenggaraan ujian di masa pandemi. Selain itu, penilaian sikap dan psikomotor juga tetap dilakukan tetapi disesuaikan dengan kondisi belajar pada masa pandemi. Berikut penggalan wawancara yang diperoleh dengan guru.

Evaluasi seperti PAS dan PTS tetap dilakukan cuma disesuaikan dengan kegiatan BDR. Untuk penilaian sikap tanggung jawab dilihat dari mengerjakan tugas atau tidak, Sikap disiplin dilihat dari mengirimkan tugas tepat waktu atau tidak, Sopan santun dilihat dari bahasa melalui chat WA, dan Penilaian prosesnya sama, ada tugas dan penilaian harian, ada juga PTS dan PAS (GE)

Untuk PTS dan PAS, setiap pagi siswa mengambil soal di sekolah kemudian dibatasi waktu pengumpulannya. Jadi kemarin siswa diberi waktu dari pukul 08.00-10.00 untuk mengambil soal sampai mengumpulkan jawabannya. Sedangkan waktu pengerjaannya diberi waktu 60menit, jadi siswa harus benar-benar jujur dengan diri sendiri. Penilaian sikap memang agak susah dilaksanakan dengan pembelajaran dari rumah bu. Paling K2 tentang nilai disiplin dan kerajinan bisa diukur dari ketepatan waktu mereka mengerjakan. Awalnya saya pernah memberikan tugas siswa melakukan kegiatan yang terkait KI 1 dan 2 lalu kegiatannya difoto tapi hanya seminggu saja tidak bisa dilakukan setiap hari. Untuk nilai ketrampilan masih bisa lebih banyak dilakukan dibandingkan dengan nilai sikap. Jadi dengan melihat KD Keterampilan, lalu memilih tugas ketrampilan yang bisa dilakukan siswa di rumah, seperti menyanyi, menggambar, menulis hasil pengamatan (SR)

Dari hasil wawancara tersebut, dapat diketahui, bahwa penilaian sikap dan penilaian psikomotor juga tetap dilakukan oleh guru tetapi disesuaikan dengan kondisi selama BDR. Namun yang menjadi keraguan bagi guru melakukan penilaian kegiatan BDR adalah apakah siswa benar-benar mengerjakan tugas tersebut secara mandiri atau dengan bantuan orang tua karena guru tidak bisa mengamati secara langsung [10]. Meskipun demikian, kegiatan PAS dan PTS tetap dilakukan dengan didukung dari hasil penilaian tugas yang dikumpulkan harian.

\section{Pembahasan}

Kegiatan BDR yang dilakukan pada masa pandemi covid-19 memberikan pengalaman baru bagi guru, siswa dan orang tua serta pelaksana kegiatan Pendidikan lainnya. Berdasarkan hasil dari penelitian, dapat diketahui jika sistem BDR menuntut peran penting antara guru dan orang tua untuk membantu siswa belajar dengan baik. Guru perlu mendesain pengalaman belajar yang bermakna bagi siswa, tanpa terbebani tuntutan menuntaskan seluruh capaian kurikulum dan menfokuskan pada pencapaian kompetensi spiritual, sikap sosial, pengetahuan, dan keterampilan/kecakapan hidup. [11]. Dengan demikian pemberian materi dan tugas lebih diarahkan kepada kecakapan hidup dan keterampilan sosial sehingga tidak membebani guru dan siswa dalam prakteknya di lapangan.

Kesulitan lain yang dihadapi guru dalam kegiatan BDR adalah pemberian materi dan tugas kepada siswa. Hal ini dikarenakan masih ada saja siswa yang malas mengumpulkan tugas yang diberikan meskipun tugas tersebut dikerjakan di rumah dan dapat dibantu oleh orang tua. Oleh sebab itu, perlunya guru menerapkan strategi pemberian tugas yang dapat diganti dengan pembuatan karya berupa lagu, puisi, essay, dan karya tulis mengenai Covid-19 [12]. Guru juga 
Jurnal Ilmiah KONTEKSTUAL, Volume.3, No.01, Agustus 2021, pp. 15-25

perlu menjelaskan tugas tersebut sebenarnya bertujuan agar siswa minimal mampu mempelajari materi yang diberikan. Selain itu, dari hasil penelitian diketahui sembilan guru bahkan melakukan tatap muka dalam pokjar untuk memantapkan materi yang sulit dijelaskan hanya dengan pembelajaran daring. Guru dapat hadir secara gagasan dalam door to door kepada siswa supaya tidak hanya membebani siswa dengan pemberian tugas yang menumpuk [13]. Pembelajaran tatap muka dalam pokjar juga dilakukan karena keterbatasan jaringan dan gadget. Hal ini dikarenakan, pembelajaran daring membutuhkan inovasi dan jaringan internet sehingga perlu disesuaikan dengan kondisi yang ada [14]

Selama kegiatan BDR, guru perlu bekerja sama dengan orang tua siswa dalam mengatur, memantau kegiatan belajar siswa. Pendampingan orang tua dalam kegiatan belajar dari rumah adalah untuk melatih kemandirian siswa dengan membiasakan siswa untuk mengerjakan tugas secara mandiri namun tetap dalam pantauan dan bimbingan orang tua [15]. Meskipun faktanya berdasarkan hasil penelitian diketahui bahwa Sebagian besar orang tua mengeluhkan kesulitan membelajarkan anaknya selama BDR, tetapi dari segi positif orang tua dituntut untuk lebih peduli dengan aktivitas belajar anak. Aktivitas Belajar Dari Rumah mendorong orang tua untuk merancang program bimbingan belajar pada anak [16]. Kegiatan belajar siswa tidak hanya menjadi tanggung jawab guru tetapi juga bekerja sama dengan orang tua sehingga perlunya komunikasi yang baik antara orang tua dan guru. Motivasi yang diberikan orang tua juga berperan penting dalam membantu proses belajar di rumah [17]

Penilaian atau evaluasi hasil kegiatan belajar juga menjadi poin penting dalam penerapan kegiatan BDR. Berdasarkan hasil survei yang dilakukan oleh Jannah dkk terhadap 117 guru SMP di Indonesia ditemukan bahwa guru mengalami kesulitan dalam proses evaluasi pembelajaran dengan metode daring, terutama pada aspek non-kognitif siswa seperti memastikan hasil pekerjaan siswa menggambarkan kemampuannya dan memanfaatkan media daring [18]. Hal senada juga ditemukan dalam penelitian ini karena guru mengaku kesulitan memeriksa apakah tugas yang dikerjakan oleh siswa benar-benar dikerjakan secara mandiri atau bekerjasama dengan orang tua. Namun, pada akhirnya dikembalikan kepada kondisi pandemi dan karakteristik siswa. Pembelajaran yang dilakukan dengan BDR bukan pembelajaran normal yang dilakukan umumnya terutama pada siswa sekolah dasar tetapi pembelajaran yang harus diterapkan karena kondisi yang luar biasa (pandemi) sehingga penilaian yang dilakukan juga disesuaikan yang ada.

\section{SIMPULAN}

Berdasarkan hasil penelitian yang telah dilakukan, dapat disimpulkan bahwa guru sekolah dasar di Purbalingga telah menerapkan kegiatan BDR. Penerapan kegiatan BDR yang dilakukan tidak sepenuhnya menggunakan pembelajaran daring tetapi blended learning karena kondisi dan karakteristik siswa. Sedangkan untuk penerapan kegiatan BDR yang dilakukan oleh guru belum sepenuhnya maksimal. Hal tersebut dikarenakan masih ditemukan kendala-kendala yang cukup berarti dan belum menemukan solusi yang efektif untuk mengatasinya. Untuk itu, perlunya peran dari pemerintah dan dinas terkait untuk menyediakan petunjuk teknis dan petunjuk pelaksaan seperti apa belajar di rumah yang sesuai dengan kebutuhan dan kondisi di daerah. Mencermati hasil dari penelitian ini, dapat dirumuskan beberapa saran untuk penelitian selanjutnya yaitu 1) menemukan metode belajar yang tepat dalam kegiatan BDR, 2) menemukan media yang mudah diakses oleh siswa, guru, dan orang tua dalam kegiatan BDR, dan 3) perlunya penelitian mengenai evaluasi atau penilaian yang dapat diterapkan pada kegiatan BDR.

\section{DAFTAR PUSTAKA}

[1] E. M. Onyema, "Impact of Coronavirus Pandemic on Education," Journal of Education and Practice, vol. 11, no. 13, pp. 108-121, 2020, doi: 10.7176/jep/11-13-12.

[2] M. Daheri, J. Juliana, D. Deriwanto, and A. D. Amda, "Efektifitas whatsapp sebagai media belajar daring," Jurnal Basicedu, vol. 4, no. 4, pp. 775-783, 2020, [Online]. Available: https://jbasic.org/index.php/basicedu/article/view/445. 
[3] F. N. Arifa, "Tantangan Pelaksanaan Kebijakan Belajar Dari Rumah Dalam Masa Darurat Covid-19," Info Singkat;Kajian Singkat Terhadap Isu Aktual Dan Strategis, vol. XII, no. 7/I, p. 6, 2020.

[4] A. R. Mansyur, "Dampak COVID-19 Terhadap Dinamika Pembelajaran Di Indonesia," Education and Learning Journal, vol. 1, no. 2, p. 113, 2020, doi: 10.33096/eljour.v1i2.55.

[5] M. Pendidikan, D. Kebudayaan, and R. Indonesia, "Pelaksanaan Kebijakan Pendidikan dalam Masa Darurat Penyebaran Coronavirus Disease(Covid-19)," surat edaran dari kemetrian RI, vol. 5, no. 2020, pp. 2013-2015, 2020.

[6] M. A. Adha, I. Arifin, M. Maisyaroh, S. Sultoni, and S. Sunarni, "Analisis Dampak Anjuran Pemerintah Terhadap Belajar Di Rumah Bagi Pelaku Pendidikan," Jurnal Administrasi dan Manajemen Pendidikan, vol. 3, no. 3, pp. 216-223, 2020, doi: 10.17977/um027v3i32020p216.

[7] R. Pakpahan and Y. Fitriani, "Analisa Pemafaatan Teknologi Informasi Dalam Pemeblajaran Jarak Jauh Di Tengah Pandemi Virus Corona Covid-19," JISAMAR (Journal of Information System, Applied, Management, Accounting and Researh), vol. 4, no. 2, pp. 30-36, 2020.

[8] Kemendikbud, "Panduan: Pembelajaran Jarak Jauh - bersama hadapi korona," Kementrian Pendidikan dan Kebudayaan, p. 4, 2020.

[9] T. Handayani, H. N. Khasanah, and R. Yoshinta, "Pendampingan Belajar Di Rumah Bagi Siswa Sekolah Dasar Terdampak Covid-19," ABDIPRAJA (Jurnal Pengabdian kepada Masyarakat), vol. 1, no. 1, p. 107, 2020, doi: 10.31002/abdipraja.v1i1.3209.

[10] D. D. Sari, "Permasalahan guru sekolah dasar selama pembelajaran daring," Jurnal Ilmiah KONTEKSTUAL, vol. 2, no. 02, pp. 27-35, 2021, [Online]. Available: http://jurnal.umus.ac.id/index.php/kontekstual/article/view/394.

[11] I. G. A. Suasthi, I. Bagus, and P. Eka, "Membangun Karakter ' Genius ' Anak Tetap Belajar Dari Rumah Selama Pandemi Covid - 19 Pada Sekolah Suta Dharma Ubud Gianyar," Cetta:Jurnal Ilmu Pendidikan, vol. 3, no. 3, pp. 431-451, 2020.

[12] A. dkk Kurniasari, "ANALISIS EFEKTIVITAS PELAKSANAAN BELAJAR DARI RUMAH (BDR) SELAMA PANDEMI COVID-19," Jurnal Review Pendidikan Dasar: Jurnal Kajian Pendidikan dan Hasil Penelitian, vol. 6, no. 3, pp. 1-8, 2020.

[13] R. H. Syah, "Dampak Covid-19 pada Pendidikan di Indonesia: Sekolah, Keterampilan, dan Proses Pembelajaran," SALAM: Jurnal Sosial dan Budaya Syar-i, vol. 7, no. 5, 2020, doi: 10.15408/sjsbs.v7i5.15314.

[14] et all Sudarsana, I Ketut., Covid-19 Perspektif Pendidikan. Yayasan Kita Menulis, 2020.

[15] R. Pangastuti, F. Pratiwi, A. Fahyuni, and K. Kammariyati, "Pengaruh Pendampingan Orangtua Terhadap Kemandirian dan Tanggung Jawab Anak Selama Belajar dari Rumah," JECED : Journal of Early Childhood Education and Development, vol. 2, no. 2, pp. 132146, 2020, doi: 10.15642/jeced.v2i2.727.

[16] N. Y. Sari and W. Wisroni, "The Urgency of Parental Guidance for Youth Education in the Belajar Dari Rumah (BDR) Era," SPEKTRUM: Jurnal Pendidikan Luar Sekolah (PLS), vol. 8, no. 3, p. 309, 2020, doi: 10.24036/spektrumpls.v8i3.109565.

[17] S. L. Iftitah and M. F. Anawaty, "Peran Orang Tua Dalam Mendampingi Anak Di Rumah Selama Pandemi Covid-19," JCE (Journal of Childhood Education), vol. 4, no. 2, p. 71, 2020, doi: 10.30736/jce.v4i2.256.

[18] Jannah et al., "Jurnal basicedu," Jurnal basicedu, vol. 5, no. 2, pp. 1060-1066, 2021. 